\title{
Empirical Analysis of Determinants of Human Capital Formation: Evidence from the Nigerian Data
}

\author{
Ubi-Abai Itoro Praise ${ }^{1, *}$, Chioma Chidinma George-Anokwuru ${ }^{2}$ \\ ${ }^{1}$ Department of Economics, Faculty of Social Sciences, University of Uyo, Uyo, Nigeria \\ ${ }^{2}$ Department of Economics, Faculty of Social Sciences, University of Port Harcourt, Choba, Nigeria
}

Email address:

ubiabai@yahoo.com (Ubi-Abai I. P.), chiomanwoga $a$ yahoo.com (C. C. George-Anokwuru)

${ }^{*}$ Corresponding author

\section{To cite this article:}

Ubi-Abai Itoro Praise, Chioma Chidinma George-Anokwuru. Empirical Analysis of Determinants of Human Capital Formation: Evidence from the Nigerian Data. Journal of World Economic Research. Vol. 7, No. 2, 2018, pp. 73-81. doi: 10.11648/j.jwer.20180702.14

Received: June 7, 2018; Accepted: June 27, 2018; Published: July 23, 2018

\begin{abstract}
The study examined the determinants of human capital formation with evidence from Nigeria. Specifically, the study sought to examine how these determinants affect human capital formation; and how they affect the growth of the Nigerian economy. The theoretical foundations of the study were the views of Adam Smith, Theodore Schultz, Gary Becker and Jacob Mincer on human capital. The data used in the study were expenditures on education, expenditures on health, total enrolments (primary, secondary, and tertiary), mortality rate, life expectancy and GDP of Nigeria. The study used trend diagrams, tabular analysis and descriptive statistics to provide answers to the first question; and the second question was answered using the three-stage least squares (3SLS) econometric technique. It was discovered that bi-directional positive and significant relationships existed between health expenditures and economic growth. Mortality rate had a positive relationship with expenditures on health. Also, bi-directional negative and significant relationships existed between education expenditures and economic growth, even when there were increased expenditures on education over the years. Total enrolments positively affected education expenditures. It was concluded that expenditures on education had not been sufficient in revitalizing the education sector. This has resulted to negative consequences in determining effective and efficient human capital formation in the economy. It was recommended that expenditures on health should be increased to ensure positive contributions to human capital formation; and government should focus on revitalizing the education sector, through effective and transparent spending, so as to have positive effects on human capital formation and the economy.
\end{abstract}

Keywords: Human Capital, Education, Health, Enrolments, Mortality, 3SLS

\section{Introduction}

Every economy strives to build a strong human capital base that is capable of contributing positively to its productivity. There can be no significant progress in any country without adequate human and natural resources. In essence, human capital formation is fundamental to a nation's economic progress Jaiyeoba [1]. It has been stressed that the differences in the level of socio-economic development across nations is attributed not so much to natural resources and endowments and the stock of physical capital but to the quality and quantity of human resources Dauda [2]. It has also been recognized that human resources are a critical variable in the growth process and worthy of development.
They are not only means but, more importantly, the ends that must be served to achieve economic progress. In addition, the wealth and prosperity of nations rest ultimately upon the development of people and the effective commitment of their energies and talents.

The active agents of modernization are human beings, for they alone can accumulate capital, exploit natural resources and build political and social organizations. Human resources constitute the ultimate basis for the wealth of nations. Capital and natural resources are passive factors of production; human beings are the active agents who accumulate capital, exploit natural resources, build social, economic and political organizations, and carry forward national development. Clearly a country which is unable to develop the skills and knowledge of its people and to utilize them effectively in the 
national economy will be unable to develop anything else Eigbiremolen, and Anuadaka [3].

The concept of human capital refers to the abilities and skills of human resources of a country, while human capital formation refers to the process of acquiring and increasing the number of persons who have the skills, education and experience that are critical for economic growth and development of a country's economyMatthew, Ogunnaike, and Fasina [4]. Furthermore, human capital refers to the human factor in the production process; and consists of the combined knowledge, skills or competencies and abilities of the workforce. Of all factors of production, only human beings are capable of learning, adapting or changing, innovative and creative. Human capital formation or development can be seen as the deliberate and continuous process of acquiring requisite knowledge, skills and experiences that are applied to produce economic value for driving sustainable national development Ejere [5]. It is imperative to note that the processes through which human capital are effectively formed are capable of driving economic and development in an economy. On the other hand, when the processes that contribute to the development of human capital are distorted, it can be detrimental to the development of an economy.

Nigeria as a country is immensely endowed both in natural and human resources. The pool of resources from one end to the other is unquantifiable to such extent that, given a dynamic leadership, economic prosperity should have been achieved. In spite of all these abundant resources, Nigeria has failed to give topmost priority to sustainable human capital formation as done by many advanced economies countries and multilateral organizations. In Nigeria, the rate of illiteracy is very high, the educational system is weak, poorly trained and uneven distribution of skilled manpower; employment crisis of human capital in different sectors of the economy; poor reward system and lack of access to basic health facilities; decayed health system and incoherent government policies on systematic human capital formation in the country.Most of the workers are poorly educated and they make use of outmoded capital, equipment and methods of production. By implication, their marginal productivity is extremely low and this leads to low real income, low savings, low investment and consequently low rate of capital formation. This poses the question of whether the government really understands the true meaning of human capital formation and recognizes the implications of human capital formation on growth and development of the Nigerian economy. It is therefore important to ask these thoughtprovoking questions:

1. What determines effective and efficient human capital formation in Nigeria?

2. How have the determinants of human capital formation affected the Nigerian economy?

The study will be of immense significance to the government and its agencies as it would assist them in providing deep insight on the level of human capital formation in Nigeria. At the individual level, this study would enable people to understand and appreciate the relevance of developing human capital in a bid to achieve economic growth. Research scholars and students interested in related field of study will find the contents of this study as useful reference source and conceptual guide.

Following from the introduction, Section II evaluates the theoretical and empirical literature reviews. Section III examines the major determinants of human capital formation in Nigeria; Section IV presents the methodology adopted for the study. Section V analyses the evidence from the Nigerian data; and Section VI concludes the study with recommendations.

\section{Literature Review}

\subsection{Theory of Human Capital Formation}

Even though research about human capital started around 1960s, Smith [6] had argued that a "general stock" of every country can be divided into three sections, one of them being a fixed capital. After listing the obvious - machines, buildings and land, he continues with "useful abilities of all inhabitants or members of the society." He stresses that people have expenses during their education, as they learn necessary skills and it can be taken as an investment in the person. This acquired skill is beneficial for the worker, as well as for the whole society and can be compared with machines which increase productivity - it has to be invested in, but it brings profit in return after sufficient amount of time.

Human capital formation theory views schooling and training as investment in skills and competences Schultz [7]. It is argued that based on national expectation of return on investment, individuals make decisions on the education and training they receive as a way of augmenting their productivity. A similar strand of studies focuses on the interaction between the educational/skills levels of the workforce and measurements of technological activities. Nelson and Edmund [8]. According to this theory, a more educated/skilled workforce makes it easier for a firm to adopt and implement new technologies, thus reinforcing returns on education and training.

In addition, education leads to increase in productivity and efficiency of workers by increasing the level of their cognitive skills. Schultz [7], Becker [9] and Mincer [10] introduced the notion that people invest in education or as to increase their stock of human capabilities which can be formed by combining innate abilities with investment in human beings Babalola [11]. Examples of such investments include expenditure on education, on-the-job training, health and nutrition. However, the stock of human capital increases in a period only when gross investment exceeds depreciation with the passage of time, with intense use or lack of use.

Human capital has also been categorised as important in itself but also important is the accumulation process which is human capital formation. This perspective stress on knowledge and skills obtained throughout educational 
activities. De la Fuente and Ciccone [12]. Lucas [13], Romer [14] drew attention to this fact in their endogenous growth theory, which proves that countries and regions which exhibit higher levels of human capital should expect higher growth rates than areas with inferior levels. Furthermore, the concept of human capital has also be defined as 'an amalgam of factors such as education, experience, training, intelligence, energy, work habits, trustworthiness, and initiative that affect the value of a worker's marginal product Becker [9]. The shift of the focus by the global economy towards more knowledge-based sectors (such as research and development, pharmaceuticals and ICT-based sectors), has encouraged policy makers to attendmore critically to skills and human capital development.

\subsection{Empirical Literature Review}

Chete and Adeoye [15] examined human capital investment on the economy and established a positive relationship between them. The study was done using regression analysis to establish relationship growth rate of real gross domestic product and investment in GDP ratio, employment rate and human capital proxied by total expenditure on education and health. The authors stated that the government appears persuaded about the directassociation between investment in human capital and economic growth but real capital expenditures on education and health sometimes slide or are deliberately cut, thus it is important for government to continue to channel more financial resources into the educational sector.

Matthew, Ogunnaike and Fasina [4] examined the relationship between human capital formation and economic growth in the Nigerian economy using secondary data from 1970-2004. The study adopted the Cobb-Douglas production function and the Ordinary Least Square method of estimation. They analysedthe relationship between real gross domestic product and economic variables such as labour force, total government expenditure on education and real gross capital formation. The empirical analysis carried out showed that labour force, government expenditure on education and real gross capital formation have a positive and significant effect on real gross domestic product with government expenditure surprisingly having the least effect. According to them, this could be attributed to misallocation by the government among the levels of education, corruption by government officials, etc. The study revealed that there exist a positive and significant relationship between human capital formation and economic growth in Nigeria.

A study on the nexus between human capital formation and economic growth was carried out on the Indian economy by Prada [16] using Granger Causality Test. The empirical results indicated that uni-directional causality existed between education and economic growth in the Indian economy and the direction of causality is from economic to education, but there is an absence of reverse causality. A short run dynamics existed between education and economic growth in India, which had been corrected to bring the Indian economy into a steady equilibrium position in the long run.
Sanyaolu, Ogunleye, Owolabi and Lawal [17]employed the ordinary least square regression analysis to examine the impact of human capital development on economic growth of Nigeria, using annual time series from 1981 to 2015. The empirical results showed that human capital development has significant impact on economic growth. Human development indicators namely secondary school enrolment, tertiary school enrolment, total government expenditure on health and total government expenditure on education exhibited positive and statistically significant impact on economic growth of Nigeria. However, life expectancy and primary school enrolment exhibited a negative and statistically insignificant impact on economic growth of Nigeria.

In an attempt to use the human capital model of endogenous growth developed by Mankiw, Romer and Weil [18], Dauda [2] examined empirically the role of human capital in Nigeria's economic development. The paper employed a variety of analytical tools, including unit root tests, cointegration tests and error correction mechanism (ECM). Empirical results indicated long-run relationship among labour force, physical capital investment proxied by real gross domestic capital formation, human capital formation, proxied by enrolment in educational institutions and economic growth in Nigeria. Findings showed that there is a feedback mechanism between human capital formation and economic growth in Nigeria.

Zhang and Zhuang [19] examined the effects of economic development by the composition of human capital in China. They use the data from different provinces of china form 1997 to 2006 by applying GMM they find endogenity and possibility of dynamics According to their results they get three divisions in provinces between education and economic development. The results highlighted that those areas where education is high economical highly developed rather than others so we can say human development plays a significant role in economic development of a country. The underdeveloped provinces relay on primary as well as secondary education, while more developed parts of China get benefits with tertiary education.

Johnson [20] evaluated the relationship between human capital formation and economic growth in Nigeria by adopting conceptual analytical framework that employs the theoretical and ordinary least square (OLS) to analyze the relationship using the GDP as proxy for economic growth; total government expenditure on education and health, and the enrolment pattern of tertiary, secondary and primary schools as proxy for human capital. The analysis confirmed that there is strong positive relationship between human capital development and economic growth.

Adawo [21] used an econometric model to examine the contributions of primary education, secondary education and tertiary education to economic growth of Nigeria. These variables were proxied by school enrolments at various levels. Other variables included physical capital formation, health measured through total expenditure on health. In all primary school input, physical capital formation and health were found to contribute to growth. Secondary school input 
and tertiary institutions were found to dampen growth.

Isola and Alani [22] evaluated the contribution of different measures of human capital formation to economic growth in Nigeria. It used data from Nigeria and adopted the growth account model which specifies the growth of GDP as a function of labour and capital. The model also included a measure of policy reforms. Based on the estimated regression and a descriptive statistical analysis of trends of government commitment to human capital development, it was found that though little commitment had been accorded health compare to education, empirical analysis showed that both education and health components of human capital development are crucial to economic growth in Nigeria.

Sieng and Yussof [23] investigated the long term relationship between human capital and economic growth in Malaysia for the period between 1981 and 2010. Based upon the results of the autoregressive distributed lag model employed, the findings indicated that a long run relationship existed between the education level of the labour force and economic growth. Among all education levels, labour with high educational attainment (secondary and tertiary) contributed positively to economic growth. The present study recommends further investment in higher education following the successful experience of many developed countries in order to propel Malaysia towards achieving its ambition of being recognised as a high income country.

Anyanwu, Adam, Obi, and Yelwa [24] investigated the relationship between human capital and economic growth in Nigeria with time series data which covered the period 19812010. Adopting the endogenous modelling approach within the autoregressive distributed lag (ARDL) framework, the bounds testing analysis indicated existence of cointegration between economic growth and human capital development indicators. Findings also showed that human capital development indicators had positive impact on economic growth in Nigeria within the reviewed periods; however, their impacts were largely statistically insignificant. Further evidence indicated that equilibrium is fully restored for any distortion in the short-run.

Osoba and Tella [25] examined the interactive effects of the relationship between human capital investment components on economic growth in Nigeria for the period of 1986 to 2014. The study employed secondary annual data on education expenditure, health expenditure, real gross domestic product and gross capital formation. The data were analysed using Fully Modified Ordinary Least Squares (FMOLS) technique. The results showed that there was positive and significant relationship between the interactive effects of human capital components and growth in Nigeria.

Paul and Akindele [26] examined the impact of human capital development on economic growth in Nigeria using time series data spanning 1980 to 2013. They set out to explore the relationship between human capital indices (education and health) and economic growth. The study employed the ARDL Co-integration analysis to estimate the relationship among the variables in the study. The findings revealed that there was a positive long-run relationship among secondary school enrolment, public expenditure on education, life expectancy rate, gross capital formation and economic growth but was statistically insignificant. The results also showed a negative long-run relationship among primary and tertiary school enrolment, public expenditure on health and economic growth.

In summary, most of the literatures reviewed used various educational indicators as a determinant of human capital formation. It is true educational variables substantially affect human capital formation. However, there are other determinants of human capital formation in Nigeria - some determinants many scholars neglected. This study seeks to incorporate the health indicators. It is necessary to give a brief analysis of the determinants of human capital formation.

\section{Research Methodology}

The study adopted the descriptive analysis and econometric approach. In estimating the model, the three stage least squares (3SLS) was applied to all the equations in the system simultaneously. The theory that guided the model was the human capital formation theory propounded by Schultz and Becker [7, 9]. According to Becker (2007) [9], the subject of health as human capital relies on three interrelated dimensions, one of which is an analysis of the ideal investments in health by all stakeholders: individuals, drug companies and governments. Also, Schultz [7], Becker [9] and Mincer [10] introduced the notion that people invest in education in order to increase their stock of human capabilities which can be formed by combining innate abilities with investment in human beings. In the light of these theories, the first equation is specified thus:

$$
\mathrm{RGDP}_{\mathrm{t}}=\mathrm{b}_{\mathrm{o}}+\mathrm{b}_{1} \mathrm{EDU}_{\mathrm{t}}+\mathrm{b}_{2} \mathrm{HLT}_{\mathrm{t}}+\mathrm{U}_{\mathrm{t}}
$$

Where GDP $_{t}$ is Gross Domestic Product at time ' $t$ '; EDU $\mathrm{t}_{\mathrm{t}}$ is expenditures on Education at time ' $\mathrm{t}$ '; $\mathrm{HLT}_{\mathrm{t}}$ is expenditures on Health at time ' $t$ '; $U_{t}$ is error term. It is expected that expenditures on health and education affect the growth of the economy positively.

With respect to health, Becker [9] focused his study mainly on mortality and the key basis of his analysis is "optimal behaviour by consumers where they maximize utility over time, subject to the resources they have, and to actions they can take to affect their survivor rates at different ages." In order to make the simultaneous equation exactly identified or balanced we specified the second equation as stated thus:

$$
\mathrm{HLT}_{\mathrm{t}}=\mathrm{b}_{\mathrm{o}}+\mathrm{b}_{1} \mathrm{GDP}_{\mathrm{t}}+\mathrm{b}_{2} \mathrm{MORT}_{\mathrm{t}}+\mathrm{U}_{\mathrm{t}}
$$

Where $\mathrm{HLT}_{\mathrm{t}}$ is expenditures on Health at time ' $\mathrm{t}$ '; MORT $\mathrm{t}$ is mortality rate at time ' $t$ '; GDP ${ }_{t}$ is Gross Domestic Product at time ' $t$ '; and $U_{t}$ is error term. It is expected that growth of the economy and mortality rate affect expenditures on health positively.

The provision of education is seen as a productive human 
capital investment, an investment which is considered by the proponents of human capital theory as equally or even more equally worthwhile than physical capital investment. These theorists stated that instruction which demands logical and analytical reasoning and which provides technical and specialized knowledge increases the marginal productivity of workers in high skill professions and positions. Acknowledging the fact that greater provision of schooling society increases national productivity and economic growth, the third equation is stated thus:

$$
\mathrm{EDU}_{\mathrm{t}}=\mathrm{b}_{\mathrm{o}}+\mathrm{b}_{1} \mathrm{GDP}_{\mathrm{t}}+\mathrm{b}_{2} \mathrm{TENROL}_{\mathrm{t}}+\mathrm{U}_{\mathrm{t}}
$$

Where $\operatorname{EDU}_{t}$ is Expenditures on Education at time ' $t$ '; GDP $_{t}$ is Gross Domestic Product at time ' $t$ '; TENROL ${ }_{t}$ is Total School enrolments at time ' $t$ '; and $U_{t}$ is error term. It is expected that growth of the economy and total school enrolment rate affect expenditures on education positively.

\section{Analytical Evidence from the Nigerian Data}

It is necessary to carry out a trend analysis of determinants of human capital formation in Nigeria. As Gujarati and Sangeetha [27] put it, "a visual plot is usually the first step in the analysis of any time series". This is relevant because it will show the behavioural patterns of the variables that forms human capital in Nigeria. Hence, the trend analyses of all variables are displayed in figure 1.

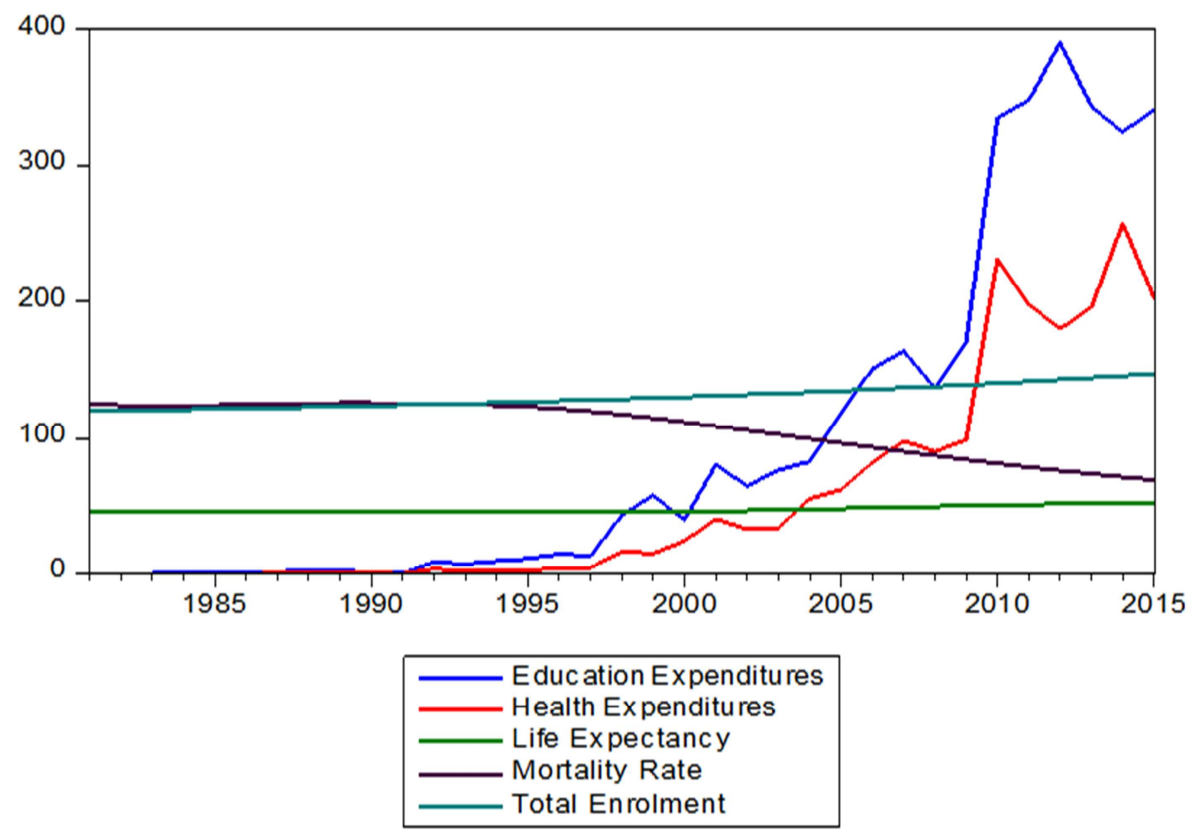

Figure 1. Trend in Education expenditures, Health expenditures, Life Expectancy, Mortality rate, and Total Enrolment in Nigeria from 1981 to 2015.

Figure 1 shows an upward trend in education expenditures since 1981, though with few periods of reduction. For example, Education expenditure in 1981 was 0.18 billion naira. It increased to 0.26 billion naira in 1985 , and 3.01 billion naira in 1988. However, it experienced reductions from 1989 to 1991 with 2.4 billion naira, 1.25 billion naira and 0.29 billion naira respectively. Expenditures in education increased drastically in 1992 to 8.88 billion naira and since maintained such trend until the year 2000 when it reduced sharply to 39.88 billion naira. It increased again to 80.5 billion naira in 2001 and has since maintained such increase, reaching peak of 341.88 billion naira in 2015 .

Health expenditures also experienced upward trend in Nigeria during the period under study, albeit some fluctuations. Health expenditure grossed 0.09 billion naira in 1981. It experienced increases and subsequently reduced to 0.04 billion naira in 1986. It sharply increased to 0.42 billion naira in 1987 and since maintained such increase until 1991 where it nosedived to 0.15 billion naira. Again, it experienced an increase in 1992 grossing 3.87 billion naira. The expenditures on health were increased in 1998 to 16.64 billion naira and grossed 34.2 billion naira in 2003. It continued such increasing trend and grossed 90.2 billion naira in the year 2008. It increased to 231.8 billion naira in 2010 and reduced to 197.9 billion naira and 179.99 billion naira in 2011 and 2012 respectively. Expenditures on health grossed 257.72 billion naira in 2014 and reduced to 202.36 billion naira in 2015 .

The average life expectancy in 1981 was 45 years. The average life expectancy increased to 46 years. It reduced to 45 years and maintained such level for the next 10 years. After, it increased to 46 years for the next 4 years. The average life expectancy for 2003 and 2004 were 47 years respectively; and the average life expectancy for 2005 and 2006 were 48 years and respectively. It increased to 49 years in 2007 and 2008; and 50 years in 2009 and 2010 respectively. Finally, it increased to 52 years in 2013 to 2015. Mortality rate in Nigeria during the period under study 
experienced a gradual downward trend. Mortality grossed 125.4 in 1981 and experienced reductions from 1982 to 1987. Mortality rate increased in 1988 and 1989 to 125.8 and 126 respectively. Mortality rate reduced to 124.4 in 1994 and 112 in the year 2000. It experienced decline in 2003, 2010 and 2015 with figures of 102.9, 81.5 and 69.4 respectively. Figure 1 also shows the trend in total enrolment during the period under study. Total enrolment comprises primary school enrolment, secondary school enrolment and tertiary enrolment.Total enrolment grossed 120.25 in 1981, and later increased to 121.30 in 1984. It increased to 125.01 in 1992 and 130.43 in 2000 . It subsequently increased to 134.92 in 2005 and 140.49 in 2010. It grossed 147.38 in 2015.

Table 1. Some Variables that determine Human Capital Formation in Nigeria.

\begin{tabular}{|c|c|c|c|c|c|c|c|c|c|c|c|c|}
\hline Year & $\begin{array}{l}\text { Pry. } \\
\text { Enrol. }\end{array}$ & $\begin{array}{l}\text { Growth } \\
\text { Rate }\end{array}$ & $\begin{array}{l}\text { Sec. } \\
\text { Enrol. }\end{array}$ & $\begin{array}{l}\text { Growth } \\
\text { Rate }\end{array}$ & $\begin{array}{l}\text { Tert. } \\
\text { Enrol. }\end{array}$ & $\begin{array}{l}\text { Growth } \\
\text { Rate }\end{array}$ & $\begin{array}{l}\text { Exp. } \\
\text { Educ }\end{array}$ & $\begin{array}{l}\text { Growth } \\
\text { Rate }\end{array}$ & $\begin{array}{l}\text { Exp. } \\
\text { Health }\end{array}$ & $\begin{array}{l}\text { Growth } \\
\text { Rate }\end{array}$ & $\begin{array}{l}\text { Mort. } \\
\text { Rate }\end{array}$ & $\begin{array}{l}\text { Growth } \\
\text { Rate }\end{array}$ \\
\hline 1981 & 98.1 & & 19.8 & & 2.38 & & 0.19 & & 0.09 & & 125.4 & \\
\hline 1985 & 97.1 & -0.01 & 21.7 & 0.09 & 2.95 & 0.24 & 0.26 & 0.37 & 0.13 & 0.44 & 124.3 & -0.01 \\
\hline 1990 & 95.8 & -0.01 & 24.3 & 0.12 & 3.84 & 0.30 & 1.26 & 3.85 & 0.62 & 3.77 & 125.9 & 0.01 \\
\hline 1995 & 94.5 & -0.01 & 27.3 & 0.12 & 4.99 & 0.29 & 11.49 & 8.12 & 3.02 & 3.87 & 123.4 & -0.02 \\
\hline 2000 & 93.2 & -0.01 & 30.7 & 0.13 & 6.51 & 0.30 & 39.88 & 2.47 & 24.52 & 7.12 & 112 & -0.09 \\
\hline 2005 & 91.9 & -0.01 & 34.4 & 0.12 & 8.48 & 0.30 & 119.02 & 1.98 & 62.25 & 1.54 & 96.6 & -0.14 \\
\hline 2015 & 89.6 & -0.01 & 43.4 & 0.12 & 14.39 & 0.30 & 341.88 & 0.02 & 202.36 & -0.13 & 69.4 & -0.14 \\
\hline
\end{tabular}

Sources: World Development Indicators, 2015

CBN Statistical Bulletin, 2015

Growth rate calculated by the Researchers

Table 1 gives the statistics on relevant indicators that determines human capital formation in Nigeria and the growth rates over the years. It is important to note that it takes a lot of processes for the formation of human capital that is capable of ensuring economic growth; and these processes of formation takes time. For example in the process of acquiring education, it is appropriate and necessary to pass through primary education, secondary education, and tertiary education. Table 1 shows education enrolment statistics at different levels that determine human capital formation in Nigeria. Primary education enrolment in 1981 grossed 98.1. It is expected that primary school enrolment increase over the years. Surprisingly, the growth rate of primary school enrolment in 1985 was negative. This trend continued in 1990, 1995, 2000, 2005, 2010 and 2015 as the periods recorded negative growth rates. This implies that the number of people that enrolled in primary school education decreased every year. This is detrimental to the formation of human capital in Nigeria.

Unlike the primary education enrolment, positive growth rates were recorded in secondary education enrolment. Table 1 show that secondary enrolment grossed 19.8. Moreover, the growth rate of secondary education enrolment was 0.09 percent in 1985 . The growth rates in secondary education enrolment increased tremendously in 1990 to 0.12 percent; 1995 to 0.12 percent; 2000 to 0.13 percent; 2005 to 0.12 percent; 2010 to 0.13 percent and 2015 to 0.12 percent. This implies that the number of people that enrolled in secondary school education increased every year. This supports the effective formation of human capital in Nigeria.

Just like the favourable growth rates experienced in secondary school enrolment, tertiary education enrolment experienced positive growth rates. Table 1 show that tertiary enrolment grossed 19.8 in 1981 and increased in 1985 with a growth rate of 0.24 percent. Tertiary education enrolment increased to 3.84 in 1990 with a growth rate of 0.30 percent. It also experienced an increase in the year 2000 and grew by 0.12 percent in 2005 to 8.48 . Subsequently, tertiary education enrolment increased in 2010 and 2015 accounting for 0.30 percent growth rates respectively.

In a bid to ensure effective human capital formation, the government spends huge sums of money in the education sector of the Nigerian economy. Statistics show that government has increased education expenditures since 1981. Expenditure on education grossed 0.19 billion naira in 1981 . Government's expenditure on education increased in 1985 with a growth rate of 0.37 percent. It also increased in 1990 with a growth rate of 0.30 percent. The education sector has since experienced increased government spending with growth rates of 2.47 percent in the year $2000,1.98$ percent in the year 2005, 1.82 percent in the year 2010, and 0.02 percent in the year 2015. It is important to note that the growth rate of expenditure on education in the year 2015 was minimal compared to previous years.

Table 1 shows that expenditure on health grossed 0.09 billion naira in the year 1981. It increased to 0.13 billion naira with a growth rate of 0.44 in 1985 . The expenditure in health increased in the year 1990 and the year 1995 with growth rates of 3.77 percent and 3.87 percent. It later increased to 24.52 billion naira and 62.25 billion naira in the year 2000 and year 2005 with growth rates of 7.12 percent and 1.54 percent growth. Also, the year 2010 experienced an increase in health expenditures by 2.72 percent. However, health expenditures nosedived to 202.36 billion naira resulting to a negative growth rate of 0.13 percent. This is not encouraging in the quest for strengthening human capital in the economy. 
Table 2. 3 Stage Least Squares Regression Results.

\begin{tabular}{|c|c|c|c|c|}
\hline Parameter & Coefficient & Standard Error & T-Statistics & Probability \\
\hline $\mathrm{C}(1)$ & 10.56269 & 0.238713 & 44.24855 & 0.0000 \\
\hline $\mathrm{C}(2)$ & 0.886487 & 0.230188 & 3.851136 & 0.0002 \\
\hline $\mathrm{C}(3)$ & -0.752806 & 0.245422 & -3.067389 & 0.0028 \\
\hline $\mathrm{C}(4)$ & -0.206223 & 0.806271 & -2.835601 & 0.0000 \\
\hline $\mathrm{C}(5)$ & 0.055835 & 0.431356 & 0.526459 & 0.0000 \\
\hline $\mathrm{C}(6)$ & 2.864971 & 0.696649 & 2.455702 & 0.0000 \\
\hline $\mathrm{C}(7)$ & 4.808057 & 0.584065 & 4.435212 & 0.0000 \\
\hline $\mathrm{C}(8)$ & -3.692123 & 0.978029 & -3.775063 & 0.0003 \\
\hline $\mathrm{C}(9)$ & 0.281333 & 0.468818 & 0.723566 & 0.0000 \\
\hline \multicolumn{5}{|c|}{ Equation: $\mathrm{LOG}(\mathrm{GDP})=\mathrm{C}(1)+\mathrm{C}(2) * \operatorname{LOG}(\mathrm{HLT})+\mathrm{C}(3) * \mathrm{LOG}(\mathrm{EDU})$} \\
\hline \multirow{2}{*}{\multicolumn{5}{|c|}{$\begin{array}{l}\text { Instruments: C MORT TENROL } \\
\text { Observations: } 35\end{array}$}} \\
\hline & & & & \\
\hline R-squared & 0.739843 & Mean dependent var & & 10.19444 \\
\hline Adjusted R-squared & 0.723583 & S.D. dependent var & & 0.519951 \\
\hline S.E. of regression & 0.273366 & Sum squared resid & & 2.391330 \\
\hline Durbin-Watson stat & 1.656607 & & & \\
\hline \multicolumn{5}{|c|}{ Equation: $\mathrm{LOG}(\mathrm{HLT})=\mathrm{C}(4)+\mathrm{C}(5) * \mathrm{LOG}(\mathrm{MORT})+\mathrm{C}(6) * \mathrm{LOG}(\mathrm{GDP})$} \\
\hline \multicolumn{5}{|c|}{ Instruments: C MORT TENROL } \\
\hline \multicolumn{5}{|c|}{ Observations: 35} \\
\hline R-squared & 0.888211 & Mean dependent var & & 1.893486 \\
\hline Adjusted R-squared & 0.881224 & S.D. dependent var & & 2.843798 \\
\hline S.E. of regression & 0.980082 & Sum squared resid & & 30.73795 \\
\hline Durbin-Watson stat & 1.948617 & & & \\
\hline \multicolumn{5}{|c|}{ Equation: $\mathrm{LOG}(\mathrm{EDU})=\mathrm{C}(7)+\mathrm{C}(8) * \mathrm{LOG}(\mathrm{GDP})+\mathrm{C}(9) * \operatorname{LOG}(\mathrm{TENROL})$} \\
\hline \multicolumn{5}{|c|}{ Instruments: C MORT TENROL } \\
\hline \multicolumn{5}{|c|}{ Observations: 35} \\
\hline R-squared & 0.952731 & Mean dependent var & & 2.718893 \\
\hline Adjusted R-squared & 0.949776 & S.D. dependent var & & 2.672153 \\
\hline S.E. of regression & 0.598847 & Sum squared resid & & 11.47578 \\
\hline Durbin-Watson stat & 1.725818 & & & \\
\hline
\end{tabular}

Source: E-Views 10.0.

Lastly, it is necessary to check mortality rate of any economy through appropriate investment in the health sector. In the case of Nigeria, mortality rate totalled 125.4 in the year 1981. It reduced to 124.3 in the year 1985 with a negative growth rate of 0.01 . Mortality increased to 125.9 with a growth rate of 0.01 percent in the year 1990 . Mortality rate have experienced negative growth rate since the year 1995. As at 2015 , mortality rate grossed 69.4 with a negative growth rate of 0.14 percent.

The next step was to adopt a better method of least squares that would account for these simultaneous correlations. This led to the adoption of the Three Stage Least Squares (3SLS) estimation technique ${ }^{1}$. In order to examine the effect of human capital formation on economic growth, the Three Stage Least Squares (3SLS) results are summarized in table 3.

Table 2 shows the factors that determine human capital formation and how these determinants of human capital formation affect growth of the Nigerian economy.From the

1The Ordinary Least Square (OLS) was not used for the estimation. This would have resulted to obviously biased estimates of the parameters and no amount of data would have improved the OLS estimates. This is because OLS is inconsistent for systems with simultaneous equation models. In other words, they are inconsistent in the face of the violated OLS assumptions. Also, the adoption of the Two Stage Least Squares (2SLS) would have led to consistent estimates of the parameters, and these would have improved with more data. But, the 2SLS is still a limited information method. It takes into account inter-temporal correlations between error terms, and ignores simultaneous correlations between various equations' error terms. This leads to inefficiency. first equation, the coefficient of expenditure on health is 0.886487. This implies that expenditure on health supported growth during the period under study. The positive relationship between expenditure on health and growth of the economy was significant at the $5 \%$ level. The coefficient value, -0.752806 , shows that there is a negative relationship between expenditure on education and GDP during the period under study. This implies that expenditures on education over the years have not supported growth of the Nigerian economy. This is contrary to a priori expectation and economic theory that expenditure on education would foster human capital formation thereby supporting the growth of the economy. The coefficient of determination shows that variations in expenditures on health and education account for $73.9 \%$ variation in the GDP.

The second equation shows the how mortality rate and gross domestic product affect expenditures on health in Nigeria during the period under study. The coefficient of mortality rate is 0.055835 . This implies that a $1 \%$ rise in mortality rate reduced expenditure on health in Nigeria during the period under study. The relationship was significant at the $5 \%$ level. Also, the coefficient of gross domestic product shows that there was a positive relationship between growth and expenditure on health in Nigeria during the period under study. This implies that as an increase in the growth of the economy increased health expenditures. This agrees with a priori expectation and economic theory. 
From the third equation, gross domestic product (GDP) and total school enrolment (TENROL) jointly explain 95.3 percent of the variations in Nigeria's expenditure on education. The result of the third equation of the three stage least square (3SLS) that gross domestic product negatively affected expenditure on education during the period under study with a coefficient of -3.692123 and probability value of 0.0003 . The results did not support the a priori expectation and economic theory that a positive relationship exist between growth of an economy and human capital formation through expenditure in education. In contrast, the relationship between enrolment and expenditure is positive, with a coefficient of 0.281333 and a probability value of 0.0000 . This implies that an increase in total enrolment prompted increase in expenditure in education to foster human capital formation.

\section{Conclusion}

The study empirically examined the determinants of human capital formation with evidence from the Nigerian data. Also, the study sought to examine how these determinants affected the human capital formation and its effects on the growth of the Nigerian economy. Using trend diagrams, tabular analysis, descriptive statistics and the econometrics technique of the three-stage least squares, it was discovered that health expenditures experienced positive growth until 2015 when it experienced negative growth. Empirically, health expenditures had a bi-directional positive and significant relationship with growth. Mortality rate experienced negative growth rates and empirically had a positive relationship with expenditures on health. Education expenditures had a bi-directional negative and significant relationship with growth despite the fact the education sector experienced growth in spending over the years. Primary enrolment experienced negative growth. However, secondary and tertiary enrolments experienced positive growth rates in Nigeria. Empirically, total enrolments positively affected education expenditures. This shows that education expenditures had not been sufficient in revitalizing the education sector despite its increasing expenditures. This has resulted to negative consequences in determining effective and efficient human capital formation in the economy. Based on the findings of the study, it is recommended that:

i. Since health expenditures affected growth positively and significantly, the government should focus on consolidating and ensure increased budgetary allocation and monitoring of funds allocated. This will strengthen the health sector and contribute positively to human capital formation and drive potential growth in the economy.

ii. There is need for the government to revitalize the education sector, through effective and transparent spending, so as to have positive effects on human capital formation and the economy. The current percentage allocated to education sector in the budget should be reviewed upwards. Moreover, all these efforts would be useless if funds are mismanaged. Similarly, government should endeavour to pay attention to the issue of quality schooling.

\section{References}

[1] Adawo, M. A. (2011). Has education (human capital) contributed to the economic growth of Nigeria? Journal of Economics and International Finance, 3(1), 46-58.

[2] Anyanwu, S. O., Adam, J. A., Obi, B., and Yelwa, M. (2015). Human Capital Development and Economic Growth in Nigeria. Journal of Economics and Sustainable Development, 6(14).

[3] Babalola, J. B. (2000). Educational Cost and financing Analysis. Ibadan: External studies progamme, University of Ibadan.

[4] Becker, G. S. (2007). Health as human capital: synthesis and extensions. Oxford Economic Papers, 59(3), 379-410.

[5] Chete, O. and Adeoye, A. (2002). Human Capital and Economic Growth: The Nigeria Evidence Human Resource Development in Africa. Nigerian Economic Society Annual Conference of the Nigerian Economic Society, pp.79-101.

[6] Dauda, R. O. (2010). Role of Human Capital in Economic Development: An Empirical Study of Nigerian Case. Oxford: Oxford Business and Economics Conference Program.

[7] De la Fuente, A. and Ciccone, A. (2002). Le capital humaindansunee'conomiemondialesur la connaissance. Rapport pour la Commission Europe enne, Brussels.

[8] Eigbiremolen, G. O., and Anuadaka, U. S. (2014) Human Capital Development and Economic Growth: The Nigeria Experience International Journal of Academic Research in Business and Social Sciences, Vol. 2

[9] Ejere, S.I. (2011). Human Capital Formation as Catalyst for National Development: Nigeria in Perspective. International Business and Management, 2(2), 98-104.

[10] Gujarati, D. N., and Sangeetha (2007). Basic Econometrics. 4th ed., New Delhi: Tata McGraw-Hill Publishing Company Ltd.

[11] Isola, W. A. and Alani, R. A. (2012). Human Capital Development and Economic Growth: Empirical Evidence from Nigeria. Asian Economic and Financial Review, 2(7), 813-827.

[12] Jaiyeoba, S. V. (2015). Human Capital Investment and Economic Growth in Nigeria. African Research Review, An International Multidisciplinary Journal, 9(1), No.36.

[13] Johnson, A. O. (2011). Human Capital Development and Economic Growth in Nigeria. European Journal of Business and Management, 3(9), 29-38.

[14] Lucas, R. E. (1988). On the Mechanics of Economic Development. Journal of Monetary Economics 22, 3-42.

[15] Mankiw, N., Romer, P., and Weil, D. (1992). A contribution to the empirics of economic growth'. A Quarterly Journal of Economics pp.407-437.

[16] Matthew, A. O., Ogunnaike, O. O. and Fasina, F. F. (2008): Human Capital Investment: Effects on Economic Growth in Nigeria (1970-2004). Labour Law Review, 2(1), pp.111-125. 
[17] Mincer, J. (1958). Investment in Human Capital and Personal Income Distribution. Journal of Political Economy, 66(4), p. 281-302.

[18] Nelson, R. R. and Edmund S. P. (1966). Investment in Humans, Technological Diffusion, and Economic Growth. American Economic Re-view, (56) 69-75

[19] Osoba, A. M. and Tella, S. A. (2017). Human Capital Variables and Economic Growth in Nigeria: An Interactive Effect. Euro Economica, 36(1).

[20] Prada (2009). Measuring Human Capital Returns. The Journal of Political Economy, 79(6), 195-121.

[21] Romer, P. (1990). Endogenous Technological Change. Journal of Political Economy 98, S71-S102.

[22] Paul, A. A. and Akindele, J. O. (2016). The impact of Human Capital Development on Economic Growth in Nigeria: ARDL Approach. IOSR Journal of Humanities and Social Science, 21(3), $1-7$.
[23] Sanyaolu, O. A., Ogunleye, O. O., Owolabi, O. A. and Lawal, O. O. (2017). Human Capital Development and Economic Growth in Nigeria. Journal of Business Management, 3(8), 17 -37 .

[24] Schultz, T. W. (1961). Investment in Human Capital. American Economic Review, 51, 117.

[25] Sieng, L. W.and I. Yussof (2014) Human Capital Accumulation and Economic Growth in Malaysia Investigating the Long Run Nexus. Malaysian Journal of Economics 48(1), 155 - 165 .

[26] Smith, A. (1976). An inquiry into the nature and causes of the wealth of nations (Vol. 1). In R. H. Campbell \& A. S. Skinner (General ed.), W. B. Todd (Textual ed.), The Glasgow edition of the works and correspondence of Adam Smith (Vol. 2). Oxford: Clarendon Press. (Original work published 1776).

[27] Zhang, C. and Zhuang, L. (2011). The Composition of Human Capital and Economic Growth: Evidence from China using Dynamic Panel Data Analysis. China Economic Review, 22(1), pp. 165-171. 